\title{
HUBUNGAN TINGKAT PENGETAHUAN TENTANG MENOPAUSE DENGAN DUKUNGAN SOSIAL SUAMI SAAT ISTRI MENGHADAPI MENOPAUSE DI DESA SOMAGEDE KECAMATAN SOMAGEDE BANYUMAS
}

\author{
Indah Yuliana Wulandari, Sitti Nur Djannah, Isti Ken Utami \\ Fakultas Kesehatan Masyarakat, Universitas Ahmad Dahlan, Yogyakarta
}

\begin{abstract}
Background: The knowledge of husband fowards menopause will help women to understand and prepare themselves in the period of menopause. Normally women will experience menopause between the ages of 45 years and 50 years. Support from her husband when the wife entering menopause can increase the confidence and the spirit of living of the wife, so that they will get a harmonic family in facing their elderly life. Goal of this research is to understand the relationship between the level of knowledge on menopause and social support of husband while the wife entering menopause in the Village of Somagede, Somagede sub district, Banyumas Regency

Method: This was an observational analytic research using cross sectional approach. The simple of this research were 70 respondents. Data collections for primary data used questionnaire.

Results: There is a relationship between the level of knowledge on menopause and social support of husband when his wife entering menopause with correlation coefficient value $(R)=0,523$ and $R$ square 0,273 , and a significant value $(\mathrm{Sig})=0,000$ lower than the alpha value $(\alpha)$, then Ha that there was a connection between the levels of knowledge about menopause with social support while the wife of the husband menopause is "received".

Conclusion: There was a relationship between the level of knowledge about menopause and social support of husband when the wife entering menopause. The level of knowledge about menopause contributes 27,3 percent of the social of support the husband when the wife entering menopause in Somagede village, Somagede sub district, Banyumas Regency.
\end{abstract}

Keywords: Knowledge, Menopause, Age

\section{PENDAHULUAN}

Kesehatan perempuan, terutama kesehatan yang berkaitan dengan fungsi reproduksi kini menjadi perhatian dunia. Masalah kesehatan reproduksi tidak hanya menyangkut kehamilan dan persalinan, namun lebih luas yaitu menarche sampai menopause. Umumnya, perempuan memiliki Umur Harapan Hidup (UHH) lebih tinggi daripada pria. Secara kodrati, perempuan mengalami fase perubahan fisiologis yang berbeda dengan pria. Fase tersebut dinamakan dengan datangnya masa menopause yang umumnya mulai terjadi pada usia 45 tahun $^{1}$.

Data Organisasi Kesehatan Dunia World Health Organization pada tahun 2007 menunjukkan, setiap tahun sekitar 25 juta wanita di seluruh dunia diperkirakan mengalami menopause. Asia menjadi wilayah dengan jumlah perempuan bergejala awal menopause tertinggi di dunia. Saat ini, umur harapan hidup (UHH) perempuan Indonesia adalah 67 tahun. Perempuan Indonesia yang memasuki masa menopause saat ini sebanyak $7,4 \%$ dari populasi. Jumlah tersebut diperkirakan meningkat menjadi $11 \%$ pada tahun 2005 dan naik lagi sebesar $14 \%$ pada tahun 2015 . Meningkatnya jumlah penduduk sebagai akibat bertambahnya populasi penduduk usia lanjut dan tingginya usia harapan hidup dibarengi membaiknya derajat kesehatan masyarakat ${ }^{2}$.

Menopause menunjukkan suatu keadaan berhentinya menstruasi. Sebelum seorang perempuan memasuki menopause akan mengalami perubahan fisik dalam 
tubuhnya, yaitu produksi hormon menurun, menstruasi tidak teratur dan keadaan fertilitas diganti dengan infertilitas. Menjelang memasuki masa menopause, banyak perempuan mengalami sejumlah gejala klinis dan psikologis yang mengganggu aktivitas sehari-hari serta menimbulkan dampak negatif terhadap kualitas hidup dan rasa percaya diri ${ }^{3}$.

Jumlah perempuan berusia 45-50 tahun di Desa Somagede mempunyai jumlah penduduk tahun 2008 sebanyak 3.764 jiwa. Desa Somagede adalah satu-satunya desa yang paling banyak memiliki perempuan usia 45-50 tahun yaitu 172 orang. Selian itu, Desa somagede memiliki wilayah yang luas dengan karakteristik responden yang bervariasi yang kemungkinan dapat berpengaruh terhadap pengetahuan suami tentang menopause.

Penelitan ini bertujuan untuk mengetahui hubungan antara tingkat pengetahuan tentang menopause dengan dukungan sosial suami saat istri menghadapi menopause Di Desa Somagede Kecamatan Somagede Banyumas.

\section{METODE PENELITIAN}

Penelitian ini merupakan penelitian Observational Analitik Cross Sectional dengan rancangan cross setional. Penelitian dilakukan di Desa Somagede Kecamatan Somagede Banyumas. Populasi dalam penelitian ini adalah seluruh kepala keluarga yang ada di Desa Somagede Kecamatan Somagede Banyumas yang istrinya berusia antara 45-50 tahun.

\section{HASIL PENELITIAN DAN PEMBAHASAN}

a) Hasil Penelitian

1) Karakteristik Responden

Tabel 1. Distribusi Frekuensi Responden Berdasarkan Pendidikan, Pekerjaan dan Penghasilan di Desa Somagede Kecamatan Somagede Banyumas

\begin{tabular}{|c|c|c|c|}
\hline No. & Karakteristik Responden & Frekuensi (n) & Prosentase (\%) \\
\hline A. & Pendidikan Terakhir & & \\
\hline 1. & Tamat SD & 45 & 64,3 \\
\hline 2. & Tamat SLTP & 8 & 11,4 \\
\hline 3. & Tamat SLTA & 14 & 20,0 \\
\hline 4. & Akademi/PT & 3 & 4,3 \\
\hline Total & 70 & 100 & \\
\hline B. & Pekerjaan Responden & & \\
\hline 1. & Petani & 6 & 8,8 \\
\hline 2. & Buruh & 43 & 61,4 \\
\hline 3. & PNS & 7 & 10,0 \\
\hline 4. & Wiraswasta & 7 & 10,0 \\
\hline 5. & Pedagang & 2 & 2,8 \\
\hline 6. & Lain-lain & 5 & 7,0 \\
\hline Total & 70 & 100 & \\
\hline C. & Penghasilan Responden & & \\
\hline 1. & Kurang dari Rp.715.000 & 50 & 71,4 \\
\hline 2. & Rp.715.000-Rp.1.000.000 & 6 & 8,6 \\
\hline 3. & Lebih dari Rp.1.000.000 & 14 & 20,0 \\
\hline
\end{tabular}

KES MAS Vol. 3, No. 3, September 2009 : 162-232 
Tabel 1 diatas menunjukkan karakteritik responden berdasarkan pendidikan terakhir, pekerjaan dan penghasilan menunjukkan bahwa sebagian besar responden dengan tingkat pendidikan terakhir adalah tamatan Sekolah Dasar (SD) sebesar 45 orang (64\%) dengan pekerjaan sebagai buruh sebesar 43 orang (61\%) dan penghasilan responden mayoritas adalah kurang dari Rp.715.000 sebesar 50 orang (71\%).

2) Deskripsi Subyek

a) Distribusi Frekuensi menurut Tingkat Pengetahuan

Tabel 2. Distribusi Frekuensi Tingkat Pengetahuan Responden Tentang Menopause di Desa Somagede Kecamatan Somagede Banyumas

\begin{tabular}{clcc}
\hline No. & Kriteria Tingkat Pengetahuan & Jumlah & Persentase \\
\hline 1. & Baik & 22 & 31,4 \\
2. & Cukup & 38 & 54,3 \\
\hline 3. & Kurang & 10 & 14,3 \\
\hline & Total & 70 & 100
\end{tabular}

Berdasarkan Tabel 2, dapat diketahui bahwa pengetahuan suami tentang menopause di Desa Somagede Kecamatan Somagede Banyumas tergolong dalam kategori cukup sebanyak 38 orang $(54,3 \%)$.

b) Distribusi Frekuensi Responden Menurut Dukungan Sosial

Tabel 3. Distribusi Frekuensi Dukungan Sosial Responden Saat Istri Menghadapi Menopause di Desa Somagede Kecamatan Somagede Banyumas

\begin{tabular}{clcc}
\hline No. & Kriteria Dukungan Sosial Suami & Jumlah & Persentase \\
\hline 1. & Tinggi & 20 & 28,6 \\
2. & Sedang & 40 & 57,1 \\
\hline 3. & Rendah & 10 & 14,3 \\
\hline & Total & 70 & 100
\end{tabular}

Berdasarkan tabel 3, dapat diketahui bahwa sebanyak 40 orang $(57,1 \%)$ orang memiliki dukungan sosial sedang.

3) Hubungan Antara Tingkat Pengetahuan Tentang Menopause Dengan Dukungan Sosial Suami Saat Istri Menghadapi Menopause di Desa Somagede Kecamatan Somagede Banyumas

Analisis yang digunakan dalam penelitian ini adalah regresi korelasi linier yaitu analisis yang bertujuan untuk mengetahui ada tidaknya dan mengetahui kuat tidaknya hubungan antara hubungan antara tingkat pengetahuan tentang menopause dengan dukungan sosial suami saat istri menghadapi menopause di Desa Somagede Kecamatan Somagede Banyumas. Berikut adalah hasil perhitungan yang telah dilakukan. 
Tabel 4. Hubungan Antara Tingkat Pengetahuan Tentang Menopause dengan Dukungan Sosial Suami Saat Istri Menghadapi Menopause di Desa Somagede Kecamatan Somagede Banyumas

\begin{tabular}{lcccccccc}
\hline Dukungan Suami & \multicolumn{9}{c}{ Tingkat Pengetahuan } \\
& \multicolumn{2}{c}{ Kurang } & \multicolumn{2}{c}{ Cukup } & \multicolumn{2}{c}{ Baik } & \multicolumn{2}{c}{ Total } \\
& $\mathrm{N}$ & $\%$ & $\mathrm{~N}$ & $\%$ & $\mathrm{~N}$ & $\%$ & $\mathrm{~N}$ & $\%$ \\
\hline Rendah & 3 & 4,3 & 7 & 10 & 0 & 0 & 10 & 14,3 \\
Sedang & 7 & 10 & 25 & 35,7 & 8 & 11,4 & 40 & 57,1 \\
Tínggi & 0 & 0 & 6 & 8,6 & 14 & 20 & 20 & 28,6 \\
\hline Total & 10 & 14,3 & 38 & 54,3 & 22 & 31,4 & 70 & 100
\end{tabular}

Berdasarkan tabel 4, diatas terlihat masing-masing kategori memiliki jumlah terbanyak yaitu tingkat pengetahuan tentang menopause kurang dengan dukungan sosial sedang sebanyak $7(10 \%)$ responden, tingkat pengetahuan suami cukup dengan dukungan sosial suami sedang sebanyak $25(35,7 \%)$ responden dan tingkat pengetahuan tentang menopause baik dengan dukungan sosial suami tinggi sebanyak $14(20 \%)$ responden.

Tabel 5. Hubungan Tingkat Pengetahuan Tentang Menopuase dengan Dukungan Sosial Suami Saat Istri Menghadapi Menopause

\begin{tabular}{|c|c|c|}
\hline $\mathrm{R}$ & R Square & Sig. \\
\hline $.523(a)$ & .273 & $.000(a)$ \\
\hline
\end{tabular}

Analisis bivariat menggunakan regresi korelasi linier. Berdasarkan analisis yang dilakukan diketahui besarnya koefisien korelasi antara variabel lingkungan keluarga dan variabel kemampuan sosialisasi menunjukan korelasi sebesar $\mathrm{R}=0,523$ dengan taraf signifikansi sebesar $0,000 \quad(0,000<0,05)$ yang berarti ada hubungan antara tingkat pengetahuan tentang menopause dengan dukungan sosial suami saat istri menghadapi menopause dengan tingkat hubungan yang positif. Arah hubungan yanag positif $(+)$ menunjukan bahwa semakin tinggi tingkat pengetahuan tentang menopause maka semakin tinggi dukungan sosial suami saat istri menghadapi menopause. Demikian pula sebalikya semakin rendah tingkat pengetahuan tentang menopause semakin rendah pula dukungan sosial suami saat istri menghadapi menopause.

Dari hasil analisis data juga didapatkan nilai $R$ Square (koefisien determinan) sebesar 0,273. Nilai koefisien determinan sebesar 0,273 menunjukan bahwa sumbangan variabel tingkat pengetahuan tentang menopause terhadap variabel dukungan sosial suami saat istri menghadapi menopause sebesar 27,3\% sedangkan sisanya disumbang oleh faktor lain.

\section{b. Pembahasan}

1) Tingkat Pengetahuan Tentang Menopause

Hasil analisis univariat menunjukkan bahwa mayoritas tingkat pengetahuan responden tentang menopause termasuk dalam kategori cukup yaitu 54,3\%. Salah satu faktor yang mempengaruhi pengetahuan seseorang adalah pengalaman dan tingkat pendidikan. Pengalaman dapat diperoleh dari pengalaman sendiri maupun orang lain. Pengalaman yang sudah diperoleh dapat memperluas pengetahuan seseorang. Secara umum, seseorang yang 
berpendidikan lebih tinggi akan mempunyai pengetahuan yang lebih luas dibandingkan dengan seseorang yang tingkat pendidikannya lebih rendah ${ }^{4}$. Hal ini dapat dilihat pada tabel 1, latar belakang pendidikan responden bahwa $64,3 \%$ yaitu pendidikan SD dan $20 \%$ berlatar belakang pendidikan SMA.

Latar belakang responden yang mayoritas pendidikan SD menunjukkan bahwa tingkat pendidikan suami yang rendah mengakibatkan kurangnya pengetahuan suami dalam menghadapi masalah, terutama saat istri memasuki menopause. Pengetahuan dapat diperoleh baik dari pendidikan formal maupun non formal. Pendidikan non formal terbentuk karena sosial budaya dalam masyarakat, adanya media cetak dan elektronik serta berdiskusi dengan teman sebaya maupun dengan tenaga kesehatan. Suami yang mempunyai tingkat pendidikan yang lebih tinggi, umumnya terbuka menerima perubahan atau halhal baru guna pemeliharaan kesehatan untuk istri yang memasuki menopause. Memang pada kenyataannya, semakin tinggi pendidikan seseorang maka semakin mudah seseorang untuk merubah tingkah lakunya. Pendidikan juga akan membuat seseorang terdorong untuk ingin tahu, mencari pengalaman sehingga informasi yang diterima akan menjadi pengetahuan ${ }^{5}$.

Berdasarkan tabel 1, menunjukkan sebagian besar responden yaitu bekerja sebagai buruh yaitu sebanyak $61,4 \%$. Pekerjaan responden juga dapat mempengaruhi pengetahuan responden tentang menopause. Pengetahuan responden yang bekerja lebih baik bila dibandingkan dengan pengetahuan responden yang tidak bekerja. Semua ini disebabkan karena responden yang bekerja di luar rumah (sektor formal) memiliki akses yang lebih baik terhadap berbagai informasi, termasuk mendapatkan informasi tentang menopause ${ }^{6}$.

Sebagian besar responden mempunyai tingkat penghasilan yaitu kurang dari Rp.715.000. Penghasilan tidak berpengaruh langsung terhadap pengetahuan responden, tetapi apabila seseorang berpenghasilan cukup besar maka akan mampu untuk menyediakan atau membeli fasilitas - fasilitas sumber informasi, tetapi sebaliknya apabila suami berpenghasilan rendah maka tidak mampu menyediakan atau membeli fasilitas sumber informasi tersebut. ${ }^{3}$

2) Dukungan sosial suami saat istri menghadapi menopause

Hasil analisis univariat menunjukkan bahwa mayoritas dukungan sosial responden saat istri menghadapi menopause termasuk dalam kategori sedang yaitu berjumlah 54,3\%. Menurut Spencer bahwa dukungan yang diberikan oleh suami sebagai orang terdekat dengan istri seperti dukungan emosional, instrumental, informasi dan penilaian dapat mengurangi rasa cemas yang dihadapi istri saat memasuki menopause ${ }^{7}$. Dukungan yang diberikan pasangan hidup tersebut dapat membuat individu merasa berharga karena masih ada seseorang yang mencintai dan memperhatikan.

Berdasarkan tabel 1, dilihat mayoritas pendidikan responden yaitu pendidikan sekolah dasar sebanyak $64,3 \%$. Hal ini pendidikan berpengaruh terhadap dukungan sosial suami, menurut Matt \& Dean cit Kodriati ${ }^{8}$ bahwa semakin tinggi tingkat pendidikan suami maka hubungan sosial suami dengan orang lain semakin luas, hal ini mengakibatkan dukungan yang diberikan suami meningkat sehingga istri yang memasuki menopause dapat menjalani masa menopausenya dengan baik. Akan tetapi suami yang berpendidikan rendah mempunyai dukungan sosial yang baik karena suami mempunyai informasi dan wawasan yang dapat menunjang pengetahuan suami tentang menopause sehingga dukungan suami kepada istri saat memasuki menopause diberikan dalam waktu yang tepat yaitu dalam masa pra menopause atau menopause awal. Hubungan pasangan suami istri yang harmonis akan memberikan 
ketenangan dan mengurangi beban yang dirasakan karena pada saat istri menghadapi tekanan dan kesulitan hidup maka istri membutuhkan suami untuk berbagi, mendengarkan atau memberikan solusi yang relevan ${ }^{9}$.

Selain itu, status pernikahan juga berpengaruh terhadap dukungan sosial suami karena status pernikahan memberikan keuntungan terhadap kesehatan seseorang. Hal ini ditegaskan oleh Ogdenbahwa pernikahan diidentifikasi sebagai sumber dukungan sosial yang efektif. Jadi status pernikahan mempunyai kontribusi dalam pemberian dukungan sosial ${ }^{10}$.

3) Hubungan Tingkat Pengetahuan Tentang Menopause dengan Dukungan Sosial Suami Saat Istri Menghadapi Menopause

Berdasarkan analisis bivariat hubungan antara tingkat pengetahuan dengan dukungan sosial suami saat istri menghadapi menopause didapatkan hasil bahwa ada hubungan yang positif antara tingkat pengetahuan dengan dukungan sosial suami saat istri menghadapi menopause di Desa Somagede Kecamatan Somagede Banyumas. Hal ini ditunjukkan dengan nilai koefisien korelasi $(R)$ sebesar 0,523 dan secara statistik bermakna dilihat dari nilai signifikan (Sig) adalah 0,000 lebih kecil dari nilai alpha $(0,05)$.

Tingkat pengetahuan suami tentang menopause dapat berpengaruh terhadap dukungan suami dalam membantu istri selama menghadapi masa menopause karena dukungan dari suami meningkatkan rasa kepercayaan diri sehingga bisa menjalani masa menopause dengan baik. Korelasi antara kedua variabel ini menunjukkan bahwa dukungan suami sangat mempengaruhi tingkat pengetahuan suami saat istri menghadapi menopause. Seseorang yang mendapatkan dukungan dari keluarga khususnya orang terdekat seperti suami dan anak-anaknya akan merasa tenang dalam menghadapi masa-masa perubahan menjelang masa menopause ${ }^{7}$.

Berdasarkan tabel 2, diketahui bahwa tingkat pengetahuan suami cukup dengan dukungan sosial suami sedang sebanyak 35,7\%. Seperti yang diungkapkan Kasdu ${ }^{11}$ bahwa pengetahuan yang cukup tentang menopause akan membantu istri dalam memahami perubahan-perubahan yang terjadi dalam dirinya dan mempersiapkan dirinya dalam menjalani masa menopause. Pendidikan yang menunjang akan memudahkan seseorang memperoleh pengetahuan yang lebih baik tentang menopause dan mempengaruhi dukungan sosial yang diberikan pada istri dalam menghadapi menopause. Pendidikan berpengaruh terhadap pengetahuan suami tentang menopause. Hal ini dikaitkan dengan tingkat pengetahuan suami bahwa seseorang yang berpendidikan lebih tinggi akan mempunyai pengetahuan yang lebih luas dibandingkan dengan tingkat pendidikan yang rendah ${ }^{4}$. Tingkat pengetahuan suami yang baik akan berpengaruh terhadap dukungan sosial dari suami karena sangat berpengaruh besar bagi istri yang akan memasuki menopause. Kuntjoro ${ }^{9}$ menjelaskan bahwa dukungan dari suami sangatlah dibutuhkan, seperti halnya perhatian emosi, informasi, instrumental dan penilaian positif karena mampu meningkatkan psikis istri saat memasuki menopause.

\section{SIMPULAN DAN SARAN}

\section{a. Simpulan}

1) Tingkat pengetahuan suami tentang menopause di Desa Somagede Kecamatan Somagede Banyumas tergolong kategori cukup. 
2) Dukungan sosial suami saat istri menghadapi menopause di Desa Somagede Kecamatan Somagede Banyumas tergolong kategori sedang.

3) Ada hubungan antara tingkat pengetahuan tentang menopause dengan Dukungan sosial suami saat itri menghadapi menopause di Desa Somagede Kecamatan Somagede Banyumas.

\section{b. Saran}

1) Kepada Petugas Kesehatan di Desa Somagede Kecamatan Somagede Banyumas, perlu memberikan penyuluhan yang menjelaskan informasi yang berkaitan dengan pengetahuan menopause dan dukungan sosial yang harus diberikan saat istri memasuki menopause. Selain itu Kader Kesehatan bisa mengadakan diskusi atau seminar yang melibatkan pasangan suami istri sehingga dapat menambah informasi kesehatan terutama yang terkait dengan menopause sehingga dapat dilakukan perbaikan pengetahuan pasangan suami istri yang salah tentang menopause.

2) Kepada Mahasiswa Fakultas Kesehatan Masyarakat Universitas Ahmad Dahlan sebagai peneliti selanjutnya yang tertarik untuk menggali lebih lanjut mengenai penelitian yang berjudul tingkat pengetahuan tentang menopause dengan dukungan sosial suami saat istri mengahadapi menopause disarankan untuk lebih memperluas populasi penelitian serta lebih memperhatikan faktor-faktor lain yang berkaitan dengan tingkat pengetahuan dan dukungan sosial suami secara mendalam karena informasi dan komunikasi tentang menopause masih kurang sehingga perlu dilakukan pendekatan yang lebih mendalam terhadap pasangan suami istri.

3) Kepada para suami di Desa Somagede Kecamatan Somagede Banyumas, perlu ditingkatkan dalam memberikan dukungan kepada istri yang memasuki menopause melalui penyuluhan atau promosi kesehatan dari petugas kesehatan.

\section{DAFTAR PUSTAKA}

1. Siagian, A., Saatnya Memperhatikan Kesehatan Wanita Usia Menopause : www.situs.kesrepro.info, 19 Mei 2009, Yogyakarta. 2007

2. Supari, S., Terjadi Pergeseran Umur Menopause : www.warmasif.co.id/ kesehatanonline/mod.php?mod=download\&op=visit\&lid=1398 ${ }_{2}$ diakses pada tanggal 08 Maret 2009, Yogyakarta.2005,

3. Baziad, A., Menopause dan Andropause, Jakarta, Yayasan Bina Pustaka Sarwono Prawihardjo, 2003

4. Notoatmodjo, Pendidikan dan Perilaku Kesehatan, Cetakan Kedua, Jakarta : Rineka Cipta, 2003

5. Desi, "Hubungan Karakteristik Demografi dan Umur Saat Menopause Dengan Keluhan Saat Menopause", Jurnal Vol 1, No 2, 2007

6. NursalamMetodologi Riset Keperawatan, Jakarta : CV Infomedika, 2001,. Spencer, R., Menopause, Jakarta, Erlangga, 2007.

7. Kodriati, N., Pengaruh Dukungan Sosial Terhadap Respon Stres Psikologi Pada Pasien Diabetes Melitus Tipe 2 Di Yogyakarta Indonesia dan Kobe Jepang, Karya Tulis IImiah, Yogyakarta : FK UGM. 2004

8. Kuntjoro, Z., Dukungan Sosial Pada Lansia : http://www.e-psikologi.com, diakses pada tanggal 08 Maret 2009, Yogyakarta, 2002

9. Ogden, J., Health Psychology : A Textbox, $2^{\text {rd }}$ Ed, Philadelphia: Open University Press, 2000

10. Kasdu, D., Kiat Sehat dan Bahagia Diusia Menopause, Jakarta, Puspa Swara, 2002 
